\title{
Clinico-Epidemiological Study of Self-Poisoning by Different Pharmaceutical Agents
}

\author{
Ahmed $\mathrm{H}^{1}$, Rahman $\mathrm{F}^{2}$, Rahman $\mathrm{M}^{3}$, Karim $\mathrm{ME}^{4}$, Sayeda $\mathrm{R}^{5}$, Rowshon $\mathrm{AHM}^{6}$, Faiz MA
}

\begin{abstract}
Background: In Bangladesh self-poisoning cases are mostly of organophosphorous compound (OPC). It is documented that $14 \%$ of all deaths amongst 10 to 50 year old women in Bangladesh were due to poisoning, the majority following suicidal ingestion of pesticides. In tertiary level hospital, a large number of self-poisoning cases are of different pharmaceutical agents, mostly from urban areas and mostly of teenager group. So the trend of self-poisoning is different in urban area than that of rural area. These pharmaceutical agent self-poisoning cases admitted into the hospitals have different modalities of clinical features with variable outcomes and socioeconomic background. But there is no actual data of these self-poisoning by the different pharmaceutical agents. Therefore, this study was aimed to describe the pattern of self-poisoning by different pharmaceutical agents. Methods: A descriptive longitudinal study was conducted in five adult medicine units of a tertiary level hospital from January 2008 to June 2008. All self-poisoned patients with different pharmaceutical agents were included with their prior informed written consent. A pre-tested questionnaire was used for data collection. Results: A total of 281 patients were interviewed. Most of the patients were female (70.8\%) with highest age range from 13 to 30 years $(91.81 \%)$. Most of the patients were students (53\%) and $40.9 \%$ were secondary school certificate pass. $60.1 \%$ patients were unmarried. Most of the patients were from urban area $(84 \%)$. The commonest background for self-poisoning was family disharmony (74.46\%). Most common offending pharmaceutical agents were benzodiazepines $(44.10 \%)$, collected mostly from local dispensary without prescription (89.33\%). Most of the patients consulted within 1 to 2 hours of poisoning (44.5\%). Commonest consultation before admission was in a Government hospital (48.40\%). Only 3 patients $(1.10 \%)$ were known to have psychiatric illness. Five patients $(1.80 \%)$ had previous history of self-poisoning. Most of the patients $(89.3 \%)$ stayed in the hospital for 1 day with no mortality. Conclusion: Self poisoning by pharmaceutical agents is common especially in urban areas. Common offending pharmaceutical agents were benzodiazepines. The commonest background for self-poisoning was family disharmony. [J Shaheed Suhrawardy Med Coll 2016;8(1): 17-22]
\end{abstract}

Keywords: Self-poisoning, Different pharmaceutical agents.

\section{Introduction}

A self-poisoning episode may be defined as the self exposure of an individual (by ingestion or inhalation) to an amount of substance associated with the significant potential to cause harm ${ }^{1}$. Self-harm has often been thought of as a problem particular to the industrialized world. Recent work has, however, begun to emphasize its importance in the developing world: the Global Burden of Disease study ${ }^{2,3}$ reported that 593000 people killed themselves in the developing world during $1990,75 \%$ of the world-wide total of deaths from self-harm ${ }^{4}$.

Many studies have shown that deliberate self-poisoning has a far higher mortality than accidental poisoning ${ }^{5-8}$. It is clear from many studies that not all people who die following acts of self-harm actually wish to die9-12. Instead, the acts are used to express rage or hostility, or to gain revenge by causing distress to another person ${ }^{13}$. In some cultures, this may be seen as the only means with which to express one's

1. Habib Ahmed, MD (Gastroenterology), Registrar, Department of Gastroenterology, Shaheed Suhrawardy Medical College Hospital, Dhaka.

2. Ferdousi Rahman, MD (Forensic Medicine) part-II student, Dhaka Medical College, Dhaka.

3. Mahbubur Rahman, Assistant Professor, Department of Gastroenterology, Uttara Adhunik Medical College Hospital, Uttara, Dhaka.

4. Mohammad Enamul Karim, Assistant Professor. Dept. of Gastroenterology, Shaheed Suhrawardy Medical College, Dhaka.

5. Sayeda Rahim, Associate Professor. Dept. of Gastroenterology, Shaheed Suhrawardy Medical College, Dhaka.

6. AHM Rowshon, Professor and Head, Dept. of Gastroenterology, Shaheed Suhrawardy Medical College, Dhaka.

7. M A Faiz, Professor (Retd.) of Medicine, Dev Care Foundation, Bangladesh, House-83, Flat-A1, Road-12/A, Dhanmondi R/A, Dhaka.

\section{Correspondence}

Dr. Habib Ahmed, MBBS, MD (Gastroenterology), Registrar, Department of Gastroenterology, Shaheed Suhrawardy Medical College Hospital Sher-E-Bangla Nagar, Dhaka, Bangladesh. Phone: +8801711121565, Email: dr.habib76@yahoo.com

Conflict of interest: No conflict of interest

Contributions by authors: All authors contributed form protocol to write up of the article 
anger with someone ${ }^{14,15}$. People who do want to kill themselves often do not succeed; in contrast, others with little or no suicidal intent die from their act ${ }^{16}$. Many factors affect the outcome, including the degree to which the poison's toxicity was understood, the speed with which the person comes to clinical attention, and the availability of effective medical treatment. It is often difficult to determine whether a person who died actually wished to do $\mathrm{so}^{13}$. The toxicity of available poisons ${ }^{17,18}$ and the paucity of medical services in the developing world ensure that the mortality rate for deliberate self-poisoning is also high, at $10-20 \%$ far higher than the $0.5-1 \%$ commonly found in industrialized countries ${ }^{19-21}$.

Agrochemical pesticides are a major public health problem throughout the developing world ${ }^{22-27}$. Organophosphate (OP) pesticides were responsible for the majority of deaths in most series of self-poisoning cases, particularly those from rural areas.

Medicines are used in cities throughout the developing world for self-harm; outside of the cities they are relatively uncommon, their prominence being replaced by pesticides. In general, they cause few deaths, particularly when compared to pesticides. However, chloroquine is an important and common exception to this rule ${ }^{13}$. CNS-acting drug is the commonest medicines used for self-harm throughout the developing world's cities. While there are few case series of antiepileptics, benzodiazepines or antidepressants ${ }^{28,29}$, barbiturates were an extremely common means of self-poisoning during the 1970s, and large series exist from this time $28,29-32$.

In Bangladesh self-poisoning cases are mostly by organophosphorous compound (OPC). A study demonstrated that $14 \%$ of all deaths amongst $10-50$-year-old women in Bangladesh were due to poisoning, the majority following suicidal ingestion of pesticides ${ }^{33}$. The majority of these cases are from rural area. In tertiary level hospital a large number of self-poisoning cases are of different pharmaceutical agents, mostly from urban areas and mostly of teenager group.

So, the trend of self-poisoning is different in urban area than that of rural area. These cases of pharmaceutical agent self-poisoning admitted into the hospitals have different modalities of clinical features with variable outcome and socioeconomic background. But there is no actual data of these self-poisoning by the different pharmaceutical agents.

Therefore reducing morbidity, mortality and future handicaps over familial, social and national economic condition, require to reduce the incidence of harmful behavior and to improve medical management of acute poisoning.

So this study was aimed to identify the common pharmaceutical agents used for self harm with their clinico-epidemiological background.

\section{Materials and Methods}

Place of study: Five adult medicine units of Dhaka Medical College Hospital, Dhaka.

Type of study: It was a longitudinal study and descriptive in nature.
Period of study: From January 2008 to June 2008.

Selection of subjects: Patients with history of self-poisoning by different pharmaceutical agents admitted in five adult medicine units of DMCH was evaluated.

Inclusion criteria:

1. Adult patients admitted in medicine units of Dhaka Medical College Hospital thorough emergency or outpatient department with a history of self-poisoning by pharmaceutical agent/agents.

Exclusion criteria:

1. Diagnosis of other causes of poisoning except self-poisoning by different pharmaceutical agents

2. Presence of any other previous organic cause of altered consciousness or coma.

3. Unwilling to give informed consent by patients or patients' relatives.

Data collection:

All data was collected in individual case record form.

Data analysis:

Data was analyzed using statistical program SPSS 11.0 Results was described as percentages. Some of the baseline characteristics of the cases were expressed as means and others as percentages.

Procedure:

There were five medicine units in Dhaka Medical College Hospital. All patients including patients of self-poisoning were get admitted in Medicine in patient departments in a twenty four hour basis.After obtaining written informed consent from the self-poisoned patient himself/ herself or from the patient's guardian, data was recorded in a pre-tested questioner.

\section{Results:}

During the period of 6 (Six) months, from January 2008 to June 2008, a total of 11747 patients were admitted in 5 (Five) adult Medicine units of Dhaka Medical College Hospital. Out of total admitted cases, 1649 (14.03\%) were poisoning cases and out of total poisoning cases, self-poisoning by different pharmaceutical agents were $281(17.04 \%)$; of them there is no death.

Table-I: Admission due to poisoning in five adult Medicine units of DMCH from January 2008 to June 2008.

\begin{tabular}{lcc}
\hline $\begin{array}{l}\text { Hospital admission profile in } \\
\text { five adult Medicine units }\end{array}$ & Number & Percentage \\
\hline $\begin{array}{l}\text { Number of patients admitted } \\
\text { Total poisoning cases }\end{array}$ & 11747 & ----- \\
$(\mathrm{n}=11747)$ & 1649 & $14.03 \%$ \\
$\begin{array}{l}\text { Self-poisoning cases by } \\
\text { different pharmaceutical }\end{array}$ & 281 & $17.04 \%$ \\
agents $(\mathrm{n}=1649)$ & & \\
\hline
\end{tabular}


Table-II: Socio-demographic features of self-poisoning cases $(n=281)$ by different pharmaceutical agents.

\begin{tabular}{|c|c|c|c|}
\hline & $\begin{array}{c}\text { Socio-demographic } \\
\text { features }\end{array}$ & Number & $\%$ \\
\hline \multirow{5}{*}{ Age (years) } & $13-20$ & 130 & 46.26 \\
\hline & $21-30$ & 128 & 45.55 \\
\hline & $31-40$ & 18 & 6.40 \\
\hline & $41-50$ & 3 & 1.07 \\
\hline & $51-60$ & 2 & 0.71 \\
\hline \multirow[t]{2}{*}{$\begin{array}{l}\text { Sex } \\
\end{array}$} & Male & 82 & 29.2 \\
\hline & Female & 199 & 70.8 \\
\hline \multirow[t]{3}{*}{ Marital status } & Married & 109 & 38.8 \\
\hline & Unmarried & 169 & 60.1 \\
\hline & Separated & 3 & 1.1 \\
\hline \multirow{6}{*}{ Occupation } & Service holder & 33 & 11.7 \\
\hline & Farmer & 3 & 1.1 \\
\hline & Student & 149 & 53 \\
\hline & House wife & 70 & 24.9 \\
\hline & Business men & 8 & 2.8 \\
\hline & Others & 18 & 6.4 \\
\hline \multirow{6}{*}{ Education } & Primary & 22 & 7.8 \\
\hline & $\begin{array}{l}\text { Secondary school } \\
\text { certificate }\end{array}$ & 115 & 40.9 \\
\hline & $\begin{array}{l}\text { Higher secondary } \\
\text { school certificate }\end{array}$ & 93 & 33.1 \\
\hline & Graduate & 46 & 16.4 \\
\hline & Above graduate & 1 & 0.4 \\
\hline & Others & 4 & 1.4 \\
\hline \multirow[t]{3}{*}{ Residence } & Urban & 236 & 84 \\
\hline & Rural & 45 & 16 \\
\hline & Islam & 262 & 93.2 \\
\hline \multirow[t]{3}{*}{ Religion } & Hindu & 18 & 6.4 \\
\hline & Christian & 1 & 0.4 \\
\hline & Others & 00 & 00 \\
\hline \multirow{4}{*}{$\begin{array}{l}\text { Monthly family } \\
\text { income }(\mathrm{Tk})\end{array}$} & $<5,000$ & 54 & 19.21 \\
\hline & $5,000-<10,000$ & 128 & 45.55 \\
\hline & $10,000-<15,000$ & 89 & 31.67 \\
\hline & $>15,000$ & 10 & 3.57 \\
\hline
\end{tabular}

Table (II) shows that majority(46.26\%) of self-poisoning cases by pharmaceutical agents were between 13 to 20 years old. Next age grouped involved 21 to 30 years $(45.55 \%)$. Female $(70.8 \%)$ were predominant over male $(20.2 \%)$. Female to male ratio was $2.43: 1$. Out of them $60.1 \%$ were unmarried and $1.1 \%$ were separated. Most of them were students (53\%). $40.9 \%$ cases were secondary school certificate pass. Only 1 case $(0.4 \%)$ was above graduate level. Most of the poisoning cases were from urban area $(84 \%)$. Muslims were predominant (93.2\%). Majority (45.55\%) family monthly income was 5,000 taka to less than 10,000 taka.
Table-III: Circumstances of poisoning

\begin{tabular}{lc}
\hline Circumstances of poisoning & $\begin{array}{c}\text { Frequency of circumstances of } \\
\text { poisoning }\end{array}$ \\
\hline Family disharmony & $70.46 \%$ \\
Fail to pass exam & $6.05 \%$ \\
Economical loss & $3.20 \%$ \\
Breaking affairs & $10.67 \%$ \\
Others & $9.61 \%$ \\
\hline
\end{tabular}

Figure (III) shows most of the circumstances of poisoning were due to family disharmony $(70.46 \%)$. Fail to pass exam $(6.05 \%)$, economical loss $(3.20 \%)$ and breaking affairs $(10.67 \%)$ were also contributing factors.

Table-IV: Drugs used for self-poisoning

\begin{tabular}{lc}
\hline Name of drugs & Frequency of poisoning \\
\hline Benzodiazepines (BDZ) & $44.10 \%$ \\
Mixed drugs & $16.70 \%$ \\
Tricyclic antidepressant agents & $7.80 \%$ \\
Other sedatives & $9.60 \%$ \\
Paracetamol & $4.60 \%$ \\
Others drugs & $11 \%$ \\
NSAIDs & $1.40 \%$ \\
Unknown drugs & $4.60 \%$ \\
\hline
\end{tabular}

Figure (IV) shows, drugs used for self-poisoning majority were benzodiazepines (44.10\%). Next to the BDZ, common drugs were mixed drugs $(16.70 \%)$, tricyclic anti-depressant agents $(7.80 \%)$, other sedatives $(9.60 \%)$, paracetamol (4.60\%), others drugs (11\%) and NSAIDs (1.40\%). 4.60\% drugs could not be identified.

Table-V: Source of drug collection

\begin{tabular}{lc}
\hline Source of drug collection & Frequency of source \\
\hline Dispensary & $89.33 \%$ \\
House hold members' using & $7.47 \%$ \\
drugs & $3.2 \%$ \\
Others & \\
\hline
\end{tabular}

Table (V) shows, most of the offending drugs were collected from dispensary (89.33\%). $7.47 \%$ drugs were collected from house hold members' using drugs.

Table-VI: Number of occasions in collecting drugs

\begin{tabular}{lc}
\hline $\begin{array}{l}\text { Number of occasions in } \\
\text { collecting drugs }\end{array}$ & $\begin{array}{c}\text { Frequency of occasions in } \\
\text { collecting drug }\end{array}$ \\
\hline At a time & $93.95 \%$ \\
At multiple occasions & $6.05 \%$ \\
\hline
\end{tabular}

Table (VI) shows most of the drugs were collected at a time $(93.95 \%)$ and rest of them collected in multiple occasions $(6.05 \%)$. 
Table-VII: Time interval between poisoning \& treatment seeking

\begin{tabular}{lc}
\hline $\begin{array}{l}\text { Time interval between } \\
\text { poisoning \& treatment seeking }\end{array}$ & $\begin{array}{c}\text { Frequency of } \\
\text { interval }\end{array}$ \\
\hline 0-1 hour & $30.20 \%$ \\
1-2 hour & $44.50 \%$ \\
2-4 hour & $19.20 \%$ \\
4-6 hour & $5.7 \%$ \\
More than 6 hour & $0.40 \%$ \\
\hline
\end{tabular}

Table (VII) shows nearly half of the patients (44.50\%) sought medical care within 1 to 2 hours. Nearly one third patients (30.20\%) within 1 hour, $19.20 \%$ patients within 2 to 4 hours and $5.70 \%$ patients within 4 to 6 hours. Only 1 patient $(0.40 \%)$ asked for medical care 6 hours after poisoning.

Table-VIII: Previous known psychiatric illness

\begin{tabular}{lc}
\hline Previous known psychiatric illness & Frequency \\
\hline Yes & $1.10 \%$ \\
No & $98.90 \%$
\end{tabular}

Table (VIII) shows only 3 patients $(1.10 \%)$ were known to have psychiatric illness.

Table-IX: Known previous history of self-poisoning

\begin{tabular}{lc}
\hline Known previous history of self-poisoning & Frequency \\
\hline Yes & $1.80 \%$ \\
No & $98.20 \%$ \\
\hline
\end{tabular}

Table (IX) shows only 5 patients $(1.80 \%)$ had previous history of self-poisoning.

Table-X: Treatment received prior to hospital admission

\begin{tabular}{lc}
\hline Treatment received prior to hospital admission & Frequency \\
\hline Yes & $77.94 \%$ \\
No & $22.06 \%$ \\
\hline
\end{tabular}

Table (X) shows majority of the patients $(77.94 \%)$ received treatment prior to hospital admission.

Table-XI: Treatment providing body before hospitalization

\begin{tabular}{lc}
\hline Treatment providing body before hospitalization & Frequency \\
\hline Govt. hospital & $48.40 \%$ \\
Private clinic & $32.40 \%$ \\
Private physician & $10.96 \%$ \\
Traditional healer & $8.22 \%$ \\
\hline
\end{tabular}

Table (XI) shows nearly half of the patients $(48.40 \%)$, who sought medical care before hospital admission, received medical care from govt. hospital. Rest of them consulted in private clinic $(32.42 \%)$, private physician $(10.96 \%)$ traditional healer $(8.22 \%)$.
Table-XII: Stomach washes of patients of poisoning

\begin{tabular}{lc}
\hline Stomach wash of patients of poisoning & Frequency \\
\hline Yes & $91.50 \%$ \\
No & $8.50 \%$ \\
\hline
\end{tabular}

Table (XII) shows most of the patients (91.50\%) were undergone stomach wash.

Table-XIII: Clinical features of self-poisoning cases by different pharmaceutical agents

\begin{tabular}{|c|c|c|c|c|}
\hline \multicolumn{3}{|c|}{ Clinical features } & Number & $\%$ \\
\hline \multirow{2}{*}{\multicolumn{3}{|c|}{$\begin{array}{l}\text { Abdominal pain } \\
\text { Vomiting }\end{array}$}} & 32 & 11.39 \\
\hline & & & 08 & 2.85 \\
\hline \multicolumn{3}{|c|}{ Diarrhea } & 00 & 00 \\
\hline \multicolumn{3}{|c|}{ Bleeding manifestations } & 00 & 00 \\
\hline \multicolumn{3}{|c|}{ Respiratory distress } & 24 & 8.54 \\
\hline \multirow{9}{*}{ Symp } & \multirow{2}{*}{\multicolumn{2}{|c|}{$\begin{array}{l}\text { Scanty micturation / } \\
\text { ceasetion of micturation }\end{array}$}} & 00 & 00 \\
\hline & & & & \\
\hline & \multicolumn{2}{|c|}{ Restless } & 58 & 20.64 \\
\hline & & Drowsiness & 178 & 63.35 \\
\hline & \multicolumn{2}{|c|}{ Convulsion } & 00 & 00 \\
\hline & \multicolumn{2}{|c|}{ Unconscious } & 10 & 3.56 \\
\hline & \multicolumn{2}{|c|}{ Anaemia } & 45 & 16.01 \\
\hline & & Cyanosis & 00 & 00 \\
\hline & \multicolumn{2}{|c|}{ Jaundice } & 00 & 00 \\
\hline \multirow{6}{*}{\multicolumn{2}{|c|}{ Pulse }} & Normal & 114 & 40.57 \\
\hline & & Tachycardia & 154 & 54.80 \\
\hline & & Bradycardia & 13 & 4.63 \\
\hline & & Normal & 253 & 90.03 \\
\hline & & Hypotension & 28 & 9.97 \\
\hline & & Hypertension & 00 & 00 \\
\hline \multirow{3}{*}{\multicolumn{2}{|c|}{$\begin{array}{l}\text { Respiratory } \\
\text { rate }\end{array}$}} & Normal & 242 & 86.12 \\
\hline & & Hypopnoea & 05 & 1.78 \\
\hline & & Tychypnoea & 34 & 12.10 \\
\hline \multirow{2}{*}{\multicolumn{2}{|c|}{ Heart }} & Normal heart sound & 281 & 100 \\
\hline & & Added sound & 00 & 00 \\
\hline \multirow{3}{*}{\multicolumn{2}{|c|}{ Lungs }} & Normal breath sound & 272 & 96.80 \\
\hline & & Crepitation & 08 & 2.85 \\
\hline & & Wheeze & 01 & 0.36 \\
\hline \multicolumn{3}{|c|}{ Temperature Normal temp } & 263 & 93.60 \\
\hline \multicolumn{3}{|c|}{ Fever } & 18 & 6.40 \\
\hline & Hypothermia & 00 & 00 \\
\hline \multirow{3}{*}{\multicolumn{2}{|c|}{ GCS }} & $>13$ & 258 & 98.81 \\
\hline & & $10-13$ & 16 & 5.70 \\
\hline & & $<10$ & 07 & 2.50 \\
\hline \multirow{3}{*}{\multicolumn{2}{|c|}{ Pupils }} & Normal & 259 & 92.20 \\
\hline & & Constricted & 19 & 6.70 \\
\hline & & Dilated & 03 & 1.10 \\
\hline
\end{tabular}

Table (XIII) shows, the most common symptom was drowsiness $(63.35 \%)$, followed by restlessness $(20.64 \%)$, abdominal pain (11.39\%), respiratory distress $(2.54 \%)$, vomiting in only 8 patients $(2.85 \%)$ and none of them had unconsciousness or convulsion. 45 patients (16.01\%) had anaemia. Tachycardia was present in $54.8 \%$ patients. 28 patients had hypotension (9.97\%). Crepitation was present in 8 patients $(2.85 \%) .18$ patients had fever $(6.40 \%)$. Most of the 
patients $(98.81 \%)$ had GCS was $>13.16$ patients had GCS in between 10 to 13 and 7 patients had GCS below 10. 19 patients $(6.70 \%)$ had constricted pupils and only 3 patients had dilated pupils.

Table-XIV: Duration of hospital stay

\begin{tabular}{lc}
\hline Duration of hospital stay & Frequency \\
\hline 1 day & $89.30 \%$ \\
$2-3$ days & $9.30 \%$ \\
$>3$ days & $1.50 \%$ \\
\hline
\end{tabular}

Table (XIV) shows most of the patients (89.30\%) stayed hospital only for 1 day. $9.30 \%$ patients stayed for 2 to 3 days. Only 4 patients (1.50\%) stayed more than 3 days.

Table-XV: Outcome of self-poisoning cases by pharmaceutical agents

\begin{tabular}{lc}
\hline $\begin{array}{l}\text { Outcome of self-poisoning cases by } \\
\text { pharmaceutical agents }\end{array}$ & Frequency \\
\hline Complete recovery & $72.24 \%$ \\
Absconded & $27.76 \%$ \\
Death & $0.0 \%$ \\
\hline
\end{tabular}

Table (XV) shows $72.24 \%$ patients had complete recovery, $27.76 \%$ patients were absconded. None of the patients died.

\section{Discussion}

During the period of 6 (six) months, from January 2008 to June 2008, total number of admission cases in 5 (Five) adult Medicine units of Dhaka Medical College Hospital were 11747 . Of them, 1649 cases $(14.05 \%)$ were due to poisoning. Out of total poisoning cases, 281cases $(17.04 \%)$ were due to self-poisoning by different pharmaceutical agents. This contributes $2.40 \%$ of total admission in all Medicine units during 6 (six) months period, which is consistent with another study ${ }^{34}(2.60 \%$ of total admission cases). Common age groups involved in poisoning were in between 13 years to 30 years $(91.81 \%)$, which is consistent with another study conducted in Francistown and Gaborone ${ }^{35}$.

Females were predominant over males $(70.80 \%$ Vs $29.20 \%$ ) and female to male ratio was $2.42: 1$ which is nearly equal to a study conducted in Piraeus, Greece, where females were $65.8 \%$ and female to male ratio was $1.92: 1^{36}$. But differ with another study35, where male to female ratio was approximately equal (58:50).

Regarding marital status, $38.80 \%$ poisoning cases were married, $60.10 \%$ were unmarried and only 3 persons $(1.10 \%)$ were separated. This figure is also consistent with the above mentioned study ${ }^{35}$.

Majority of the cases were students $(53 \%)$, followed by house wives $(24.90 \%)$, service holder $(11.70 \%)$, business men $(2.8 \%)$ and farmers $(1.1 \%)$. The high incidence among the students reflects that they are emotionally vulnerable group and among the housewives indicates that familial instability is the underlying cause. This result differs from the study36 mentioned above, where students were $14.60 \%$, house wives were $40.60 \%$ and service holders were $15.60 \%$.

Regarding education, those who received secondary school certificate education were more common (40.90\%), followed by those who received higher secondary school certificate education $(33.10 \%)$. This result is also consistent with the study ${ }^{36}$ mentioned above.

Most of the poisoning cases were from urban area (urban $84 \%$ Vs rural $16 \%$ ), which is different from that of other type of poisoning ${ }^{33}$. Muslims were predominant (93.20\%). Majority of the family's monthly income was between $5,000 \mathrm{Tk}$ to $10,000 \mathrm{Tk}$.

Family disharmony (70.46\%) was common background for self-poisoning. Breaking affairs $(10.67 \%)$ was the next common circumstance. This differs from a study conducted in Hong Kong ${ }^{37}$.

Different drugs were used for self-poisoning. Benzodiazepines were the commonest drugs (44.10\%). Next to the BDZ, common drugs were mixed drugs $(16.70 \%)$, tricyclic anti-depressant agents $(7.80 \%)$, other sedatives $(9.60 \%)$, paracetamol $(4.60 \%)$, others drugs $(11 \%)$ and NSAIDs (1.40\%). $4.60 \%$ drugs could not be identified. This result differs from the study ${ }^{34}$ mentioned above, where barbiturates were the commonest drugs $(51 \%)$ and benzodiazepines were the next common drugs (49\%) used for self-poisoning.

Most of the offending drugs were collected from dispensary (89.33\%). $7.47 \%$ drugs were collected from house hold members' using drugs. And most of the drugs were collected at a time $(93.95 \%)$ and rest of them collected in multiple occasions $(6.05 \%)$, which mightindicate pre planned self-poisoning.

Nearly half of the patients $(44.50 \%)$ sought medical care within 1 to 2 hours. Nearly one third patients (30.20\%) within 1 hour, $19.20 \%$ patients within 2 to 4 hours and $5.70 \%$ patients within 4 to 6 hours. Only 1 patient $(0.40 \%)$ asked for medical care 6 hours after poisoning.

Out of the 281 patients, only 3 patients $(1.10 \%)$ were known to have psychiatric illness, which differs from the study ${ }^{36}$ mentioned above, where known psychiatric illness was present in $38.3 \%$. This may be due to low incidence of psychiatric illness or under diagnosis in our country.

Majority of the patients (77.94\%) received treatment prior to hospital admission. And nearly half of the patients $(48.40 \%)$, who sought medical care before hospital admission, received medical care from govt. hospital. Rest of them consulted in private clinic $(32.42 \%)$, private physician $(10.96 \%)$ co based practitioner $(8.22 \%)$. Most of the patients $(91.50 \%)$ were undergone stomach wash.

Regarding clinical feature, the most common symptom was drowsiness $(63.35 \%)$, followed by restlessness $(20.64 \%)$, abdominal pain $(11.39 \%)$, respiratory distress $(2.54 \%)$, vomiting $(2.85 \%)$ and none of them had unconsciousness or convulsion. 45 patients (16.01\%) had anaemia. Tachycardia was present in $54.8 \%$ patients. 28 patients had hypotension $(9.97 \%)$. Crepitation was present in 8 patients $(2.85 \%) .18$ patients had fever $(6.40 \%)$. Most of the patients had GCS was $>13,16$ patients had GCS in between 10 to 13 and 7 patients had GCS below 10. Only 19 patients $(6.70 \%)$ had constricted pupils and only 3 patients had dilated pupils.

Most of the patients (89.30\%) stayed hospital only for 1 day. $9.30 \%$ patients stayed for 2 to 3 days. Only 4 patients $(1.50 \%)$ stayed more than 3 days. Out of total patients, $72.24 \%$ patients had complete recovery, $27.76 \%$ patients were absconded. None of the patients died. 


\section{Limitation of study}

This was a descriptive study conducted only a period of six months. If it was conducted for long time i.e. 12 months, more patients would be included and result would be more authentic to describe the epidemiology of self-poisoning by different pharmaceutical agents. A significant number of patients were absconded. Their exact final outcome was not known. A large proportion of drugs used for self-poisoning were not recognized. Their identification might have valuable information regarding drugs used for self-poisoning. Finally, most of the patients did not undergo psychiatric evaluation. That's why this study did not ascertained exact circumstances of poisoning.

\section{Conclusion}

In urban area, a large portion of this poisoning cases occurred by ingestion of drugs. Most of the affected cases were below 30 years old. The most important circumstances of poisoning were family disharmony and breaking of affairs. Most of the drugs were collected from dispensary without prescription.

\section{References}

1. D. R. Camidge, R. J. Wood \& D. N. Bateman. The epidemiology of self-poisoning in the UK. Br J ClinPharmacol, 56, 613-619.

2. Murray CJL, Lopez AD. The global burden of disease: a comprehensive assessment of mortality and disability from diseases, injuries and risk factors in 1990 and projected to 2020. [Global Burden of Disease and Injury Series. Volume 1]. Cambridge MA, Harvard School of Public Health, 1996

3. Murray CJL, Lopez AD. Global Burden of Disease Study-Summary. Lancet1997; 349:1269-76.

4. Murray CJL, Lopez AD. Global health statistics. A compendium of incidence, prevalence and mortality estimates for over 200 conditions. [Global burden of disease and injury series. Volume II]. Cambridge MA, Harvard School of Public Health and WHO, 1996.

5. Hettiarachchi J, Kodithuwakku GCS. Pattern of poisoning in rural Sri Lanka. Int J Epidemiol1989; 18:418-22.

6. Ingianna J, Herrero R, Albertazzi C. Estudio comparativo de casos de intoxicaciones por insecticidas organofosforados en diferentes zonas de Costa Rica. Revista Biol Trop1983; 31:139-44.

7. Abdollahi M, Jalali N, Sabzevari O, Hoseini R, Ghanea T. A retrospective study of poisoning in Tehran. Clin Toxicol1997; 35:387-93.

8. Sinitox. Revisao da estatistica de 1997. Casos de intoxicacao e envenenamento. Brasil, 1997.

9. Hawton K. Deliberate self-harm. Medicine1997; 24:77-80.

10. Hawton K, Catalan J. Attempted suicide: a practical guide to its nature and management. Oxford, Oxford Medical Publications, 1987.

11. Abu Al-Ragheb S, Qaryoute S, el-Muhtaseb H. Mortality of burn injuries in Jordan. Burns, including Thermal Injury1984; 10:439-43.

12. Williams H, Buchan T. A preliminary investigation into parasuicide in Salisbury, Zimbabwe-1979/1980. Central Afr J Med1981; 27:129-35.

13. M. Eddleston. Patterns and problems of deliberate self-poisoning in the developing world.Q J Med 2000; 93:715-731.

14. Maracek J. Psychological approaches to understanding suicide. In: De Silva P, ed. Suicide in Sri Lanka. Kandy, Institute of Fundamental Studies, 1989:16-24.
15. De Silva P. The logic of attempted suicide and its linkage with human emotions. In: De Silva P, ed. Suicide in Sri Lanka. Kandy, Institute of Fundamental Studies, 1989:25-40.

16. Kessel N. Self-poisoning. Br Med J1965; ii: 1265-70, 1336-40.

17. van der Hoek W, Konradsen F, Athukorala K, Wanigadewa T. Pesticide poisoning: a major health problem in Sri Lanka. SocSci Med1998; 46:495-504.

18. Hettiarachchi J, Kodithuwakku GCS. Self-poisoning in Sri Lanka: factors determining the choice of the poisoning agent. Human Toxicol1989; 8:507-10.

19. Jacobsen D, Frederichsen PS, Knutsen KM, Sorum Y, Talseth T, Odegaard OR. Clinical course in acute self-poisoning: a prospective study of 1125 consecutively hospitalised adults. Hum Exp Toxicol1984; 3:107-16.

20. Pond SM, Lewis-Driver DJ, Williams GM, Green AC, Stevenson NW. Gastric emptying in acute overdose: a prospective randomised controlled trial. Med J Aust1995; 163:345-9.

21. Bailas MC, Reid PG, Beck P, et al. Changing patterns of self-poisoning in a UK health district. Q J Med1996; 89:893-901

22. Wiese IH. Pesticides and the South African population. S Afr Med J1976; 50:1801-5.

23. Singh PDA, West ME. Acute pesticide poisoning in the Caribbean. West Indian Med J1985; 34:75-83.

24. Keir N, Whiting N. A study of pesticide-related suicide. London, Befrienders International, 1997.

25. Forget G. Pesticides and the third world. J Toxicol Env Health1991; 32:11-31.

26. Garcia JE. Intoxicaciones agudas con plaguicidas: costos humanos y economicos. Pan Am J Public Health1998; 4:383-7.

27. Wesseling C, McConnell R, Partanen T, Hogstedt C. Agricultural pesticide use in developing countries: health effects and research needs. Int J Health Services1997; 27:273-308.

28. da Silva OA, Lopez M. Tratamento intensivo das intoxicacoes exogenas agudas. Rev Assoc Med Brasil1980; 26:4-6.

29. Agarwal SK, Tiwari SC, Dash SC. Spectrum of poisoning requiring haemodialysis in a tertiary care hospital in India. Int J Artif Organs1993; 16:20-2.

30. Kuo TL, Chen WY, Fong JM, How SW. Studies on serum barbiturate levels of acute intoxication. J Formosan Med Assoc 1984; 83:135-41.

31. Singh S, Sharma BK, Wahi PL, Anand BS, Chugh KS. Spectrum of acute poisonings in adults (10 year experience). J Assoc Physicians India1984; 32:561-3.

32. Gupta SK, Grover JK, Bhardwaj SL, Sahak T, Basu N. Blood barbiturate levels in 175 suspected suicide patients. J Assoc Physicians India1984; 32:340-2.

33. Yusuf HR, Akhter HH, Rahman MH, Chowdhury MK, Rochat RW. Injury-related deaths amongst women aged 10-50 years in Bangladesh, 1996-97. Lancet2000; 355:1220-4.

34. Ray JE, Reilly DK, Day RO. Drugs involved in self-poisoning: verification by toxicological analysis. Med J Aust. 1986 Apr 28; 144(9):455-7.

35. Malangu N. Characteristics of acute poisoning at two referral hospitals in Francistown and Gaborone. SA FamPract 2008; 50(3):67.

36. CharalambosTountas, AlexiosSotiropoulos, Stathis A Skliros, VasilikiKotsini, Theodoros A Peppas, Elias Tamvakos and Stavros Pappas. Voluntary self-poisoning as a cause of admission to a tertiary hospital internal medicine clinic in Piraeus, Greece within a year. BMC Psychiatry $2001 ; 1: 4$.

37. K.C. Yeung and T.W. Wong.Poisoning - An Epidemiological Study. Journal of the Hong Kong Medical Association1990; Vol. 42, No.4. 